\title{
Cinsel performans artırıcı bitkisel ürün ilişkili akut genç iskemik inme
}

\author{
Acute young ischemic stroke associated with herbal drug used to improve sexual \\ performance
}

Fettah Eren, Aydın Talip Yıldoğan, Gözde Öngün, Recep Aygül

Gönderilme tarihi: 14.07.2018

Kabul tarihi:12.10.2018

\section{Özet}

Birçok kişi, herhangi bir hekim tarafından tavsiye edilmeksizin, bitkisel ve gıda takviyesi diye adlandırılan ürünlere kolaylıkla ulaşabilmektedir. Televizyon, internet ve gazetelerde yayınlanan sık reklamlar nedeni ile hastaların bu ürünlere talebi artmaktadır. Fakat denetimsiz ve reçetesiz alınan ürünler birçok hastalığa zemin hazırlayabilmektedir. Otuz dört yaşında erkek hasta ani gelişen konuşmada bozulma, sol kol ve bacakta güç kaybı ve ajitasyon nedeni ile getirildi. Nörolojik muayenesinde; bilinci konfüze ve kooperasyonu kısıtlıydı. Sol hemiparazi (4/5) ve solda Babinski belirtisi pozitifliği saptandı. Beyin manyetik rezonans görüntüleme akut iskemi ile uyumlu difüzyon kısıtılığı olduğunu gösterdi. Hastanın kooperasyonu düzeldikten sonra özgeçmişi tekrar sorgulandı. Son 1 haftadır arjinin, karnitin, boswellia serrata, kafein, tribulus terrestris, epimedium, beta glukan, niasin, çinko, CoQ10, tiamin, riboflavin, vitamin B6 ve selenyum içeren cinsel performansı artırdığı iddia edilen bir ürünü kullandığı öğrenildi. Genç iskemik inme yönünden tüm tetkikleri tamamlanan hastada başka risk etmeni tespit edilmedi. Bu tablonun kullanılan ürüne bağlı olabileceği düşünüldü. Bitkisel ya da gıda takviyesi diye adlandırılan ürünlerindeki birçok bileşene bağlı farklı yan etkiler izlenebilmektedir. Hastalar ve toplum bu ürünler hakkında bilgilendirilmelidir. Bu ilaçlar üzerine bilimsel araştırmalar artırılmalı ve yasal düzenlemeler yapılmalıdır.

Anahtar Kelimeler: Bitkisel ilaç, cinsel işlev bozukluğu, genç iskemik inme.

Eren F, Yıldoğan AT, Öngün G, Aygül R. Cinsel performans artırıcı bitkisel ürün ilişkili akut genç iskemik inme. Pam Tıp Derg 2019;12:177-180.

\begin{abstract}
Many people can easily access the drugs called herbal and food supplement without recommended by any doctor. Demand of these drugs is increasing by patients due to frequent advertising on television, internet and newspapers. However, uncontrolled and over the counter drugs can cause many side effects. A thirty four year old male patient presented with acute speech disorder, left hemiparesis and agitation. In his neurological examination; confusion and cooperative limitation were detected. Left hemiparesis $(4 / 5)$ and positive left Babinski sign was detected. Brain magnetic resonance imaging showed diffuse restriction like acute ischemia. After the patient's cooperation improved, the background was again questioned. It was learned that he has been taking herbal drugs to improve his sexual performance for 1 week. The contents of the drug were arginine, carnitine, boswellia serrata, caffeine, tribulus terrestris, epimedium, beta glucan, niacin, zinc, CoQ10, thiamine, riboflavin, vitamin B6 and selenium. All tests were completed for young ischemic stroke and no other risks were detected. It was thought that this disease may depend on herbal drug. There are many side effects associated with many contentsts of herbal or food supplement drugs. Patients and society should be informed about these drugs. Scientific research on these drugs should be increased and legal regulations should be made.
\end{abstract}

Key words: Herbal drug, sexual dysfunction, young ischemic stroke.

Eren F, Yıldoğan AT, Öngün G, Aygül R. Acute young ischemic stroke associated with herbal drug used to improve sexual performance. Pam Med J 2019;12:177-180.

Fettah Eren, Uzm.Dr. Sağlık Bilimleri Üniversitesi, Konya Eğitim ve Araştırma Hastanesi, Nöroloji Kliniği, KONYA, e-posta:dreren42@hotmail.com (orcid.org/0000-0001-6834-0827) (Sorumlu yazar)

Aydın Talip Yıldoğan, Arş.Gör. Selçuk Üniversitesi Tıp Fakültesi, Nöroloji Anabilim Dalı, KONYA, e-posta:ta lip_38@hotmail.com (orcid.org/00000002-9482-6203)

Gözde Öngün, Arş.Gör. Selçuk Üniversitesi Tıp Fakültesi, Nöroloji Anabilim Dalı, KONYA, e-posta:gongun68@hotmail.com (orcid.org/0000-00023202-2410)

Recep Aygül, Prof.Dr. Selçuk Üniversitesi Tıp Fakültesi, Nöroloji Anabilim Dalı, KONYA, e-posta:raygul@selcuk.edu.tr (orcid.org/0000-0002-36032480) 


\section{Giriş}

Teknolojinin ve ilaçların hızla geliştiği günümüzde, ilaç kullanmama eğilimi de hızla artmaktadır. Medya tarafından da tüm ilaçların aslında bitkilerden yapıldığı söylemi abartılarak gündeme getirilmektedir. Bu yüzden doğal ve bitkisel ürünlerin güvenle kullanılabileceği ve bunların tamamen zararsız olduğuna vurgu yapılmaktadır.

Bitkisel ürünler çeşitli mağaza, televizyon ve internet ortamından kolaylıkla temin edilebilmektedir. Bu ürünler üzerinde tıbbi ilaçlar gibi geniş kapsamlı araştırma yapılmamaktadır. Içerdikleri maddeler, bu maddelerin etkileri, dozları, aktif metabolitlerinin kana geçiş miktarı ve ilaç etkileşimleri tam olarak bilinmemektedir. Ayrıca bu ilaçların yan etkileri hakkında da yeterli bilgi yoktur. Bileşiminde bulunan fitokimyasallar, farmakokinetik ve farmakodinamik mekanizmaları ile özellikle fibrinolitik sistemi etkileyebilmektedir. Bu etkileri nedeni ile antikoagulan tedavi kullanan hastalarda tromboz veya kanama komplikasyonu meydana getirebilmektedir [1-3].

Cinsel işlev bozukluğu, oldukça sık rastlanan sorunlardandır. Toplumda yaklaşık üç kişinin biri hayatlarının bir döneminde cinsel işlev bozukluğu yaşamaktadır. Kadınlarda, cinsel istekte azalma, orgazm bozukluğu ve vajinismus; erkeklerde ise erektil disfonksiyon, prematüre ejakülasyon ve cinsel istek azığı en sık görülen sorunlardandır $[4,5]$. Çok sık görülmelerine ve başarılı bir şekilde tedavi edilmelerine rağmen maalesef $\mathrm{ki}$ cinsel yakınmalar ile hekime başvuru oranı oldukça düşüktür. Özellikle bizim gibi daha içe kapalı toplumlarda kültürel ve toplumsal etkenler nedeni ile bu sorunların paylaşıması daha azdır. Bu nedenle ulaşımı ve temini daha kolay ürünler ile daha gizli şekilde tedaviye ulaşma yolları aranmaktadır. Reklamı daha fazla yapılan, yan etkilerinin olmadığı vurgulanan ve bitkisel olduğu iddia edilen ürünler bu nedenle tercih edilmektedir. Bu ürünlerin bu şekilde bilinçsiz olarak kullanımı ciddi nörolojik hastalıklar meydana getirebilmektedir.

\section{Olgu}

Otuz dört yaşında erkek hasta ani gelişen konuşmada bozulma, sol kolve bacakta güç kaybı ve ajitasyon nedeni ile başvurdu. Yakınmalarının 8 saat önce uykudan uyandıktan sonra başladığı öğrenildi. Nörolojik muayenesinde; bilinci konfüze ve kooperasyonu kısıtlıydı. Sol kol ve bacakta $4 / 5$ kas gücü kaybı vardı. Solda Babinski belirtisi pozitifti. Derin tendon refleksleri sol üst ve alt ekstremitede hipoaktifti. Solda hemihipoestezi belirlendi. Destekli olarak yürüyebiliyordu. Özgeçmişinde herhangi bir hastalık ve travma bulunmamaktaydı. 10 yıldır, günde 1 paket sigara kullanımı vardı. Alkol ve uyuşturucu madde kullanımı yoktu.

Difüzyon ağırlıklı beyin manyetik rezonans görüntüleme (MRG) sağ oksipital, sağ talamus posterolaterali, sağ talamus anteromediali ve sol serebellar hemisfer anteromedialinde hiperintensite olduğunu gösterdi (Resim 1A, 1B). Aynı bölgelerin görünüşteki difüzyon katsayısı (ADC) haritasında hipointens olduğu görüldü (Resim 1C, 1D). Bilgisayarlı tomografi (BT) de ise bu bölgeler hipodensti (Resim 1E). Beyin BT ve MRG bulguları akut iskemik inme ile uyumluydu. Vital bulgularından ateşi $37,8^{\circ} \mathrm{C}$ ve kan basıncı 160/80 mmHg idi.

Laboratuvar tetkikleri değerlendirildi. WBC $=6,27 \mathrm{~K} / \mathrm{uL}(3,5-10,5)$, hemoglobin $=13,2$ g/dL (13,5-17,5), trombosit=135 K/uL (150-
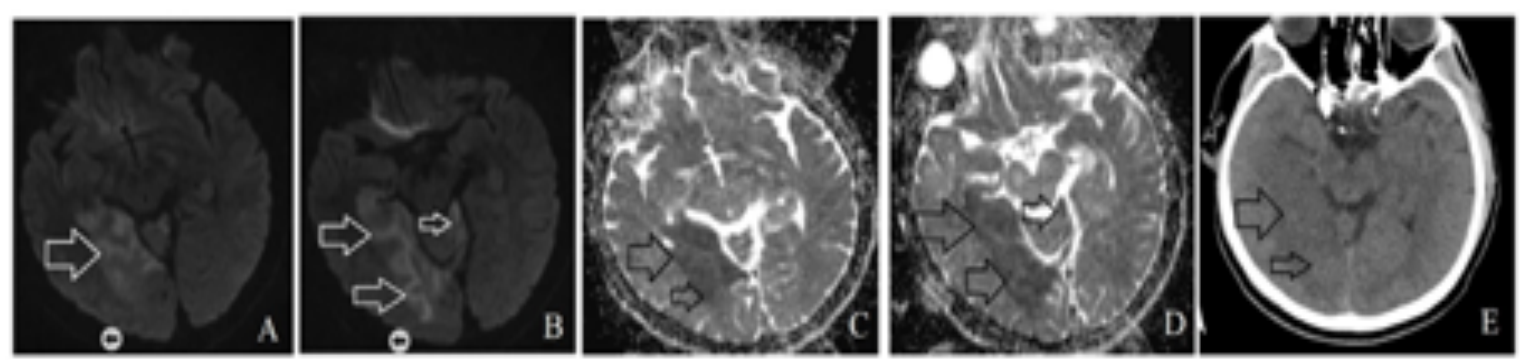

Resim 1. A,B: Manyetik rezonans görüntüleme, difüzyon ağılıklı sekans; sağ oksipital, sağ talamus posterolaterali, sağ talamus anteromediali ve sol serebellar hemisfer anteromedialinde hiperintensite. C,D: Görünüşteki difüzyon katsayıSı (ADC) haritası; aynı bölgede hipointense. E: Bilgisayarlı tomografi; aynı alanlarda hipodansite. 
450), B12=365 pg/mL (211-911), folik asit=17/ $\mathrm{mL}$ (9-24) bulundu. Karaciğer fonksiyon testleri, kreatinin fosfokinaz, total kolesterol, trigliserid, düşük dansiteli lipoprotein (LDL), yüksek dansiteli lipoprotein (HDL), elektrolitler ve kan gazı normal sınırlardaydı. Kan şekeri=116 $\mathrm{mg} / \mathrm{dL} \quad(70-110)$, kreatin=0,76 $\mathrm{mg} / \mathrm{dL} \quad(0,7-$ 1,2), üre=78,9 mg/dL (18-55), $\mathrm{HbA} 1 \mathrm{C}=5,8$ (4-6) olarak belirlendi. Prokalsitonin $=0,32 \mathrm{ng} /$ $\mathrm{ml} \quad(0,1-0,5), \quad \mathrm{CRP}=6,78 \mathrm{mg} / \mathrm{L} \quad(0-5)$ ve sedimantasyon=13 m/h (0-20) idi. ANA=negatif, ANCA=negatif, Anti DS-DNA=negatif, Anti kardiyolipin IGG/IGM=negatifti. $R F=13,88 \mathrm{mg} / \mathrm{L}$ (0-20), IGG=12,6 g/L (7-16), IGM=1,16 g/L (0,42,3), C3=1,46 g/L $(0,9-1,8), C 4=0,39 \mathrm{~g} / \mathrm{L}(0,1-$ $0,4)$ ile normal aralıktaydı. TSH=0,78 $\mu \mathrm{lU} / \mathrm{mL}$ $(0,56-5,57)$, serbest T3, T4, tiroglobulin ve tiroid oto antikorları normaldi. D dimer, fibrinojen, protombin zamanı, homosistein, protein $\mathrm{C}$, protein $S$ ve antitrombin 3 sonuçları normaldi. Faktör 5 Leiden ve protombin gen mutasyonu saptanmadı.

Elektrokardiyografi (EKG) normaldi. Ekokardiyografide ejeksiyon fraksiyonu \%65 idi. Sol ventrikül duvar hareketleri ve çapları, asendan aorta ve kalp kapakları normaldi. Yetmiş iki saat boyunca takılı kalan EKG holterde aritmi gözlenmedi. Transözafagial ekokardiyografi (TEE) normaldi. Karotis ve vertebral arter renkli doopler ultrason (USG) incelemesinde karotis arter distalinde $4 \times 2 \mathrm{~mm}$ boyutlarında kalsifiye plak belirlendi.

Hasta antiagregan tedavi altında takip edildi. Kan basıncı antihipertansif tedaviye gerek kalmadan normal seviyelere geriledi. Bilinç durumu düzeldikten sonra tekrar özgeçmişi ve kullanmış olduğu ilaçlar sorgulandı. Hastanın son 1 haftadır arjinin, karnitin, Boswellia serrata, kafein, tribulus terrestris, epimedium, beta glukan, niasin, çinko, CoQ10, tiamin, riboflavin, vitamin B6 ve selenyum içeren cinsel performansı artırdığı iddia edilen bir ürünü internetten sipariş ile alıp kullandığı öğrenildi. Bu ürünü sabah, akşam düzenli olarak ve cinsel ilişkiden 1 saat önce almaktaymış. Son ilaç dozunu ise inmeden bir gün önce, gece yatmadan önce aldığını ifade etti. Bu ürünün bitkisel olduğu ve prematüre ejakülasyon için toplum tarafından tercih edildiği anlaşıldı.

Hastanın mevcut durumunun etiyolojisi kullanmakta olduğu ürüne bağlandı. 1 ay sonra poliklinikte tekrar değerlendirildiğinde kas gücü defisiti yoktu. Desteksiz olarak yürüyebiliyordu. Günlük hayatını bağımsız şekilde devam ettirebiliyordu.

\section{Tartışma}

Cinsel işlev bozuklukları toplumda oldukça sık görülmektedir. Her üç erkekten biri hayatlarının en az bir döneminde cinsel işlev bozukluğu yaşamaktadır. Ancak bu sorunun büyüklüğü hekime ve sağlık kuruluşuna başvuru oranı, çevre ile ne ölçüde paylaşıldığı ve tedaviye ulaşma durumu ile yakından ilişkilidir. Bu durumlar göz önüne alındığında cinsel işlev bozukluğu günümüzde önem kazanmaya başlamıştır. Bu bozukluklar içerisinde yaşam boyu prevalansı en fazla olan cinsel isteksizliktir. Erektil disfonksiyon ikinci, prematüre ejakülasyon ise üçüncü sıklıkta yer alan cinsel işlev bozukluklarındandır [6].

Prematüre ejakülasyon, \%20-30 gibi yüksek oranlar ile tüm toplumlarda sık rastlanan bir cinsel işlev bozukluğudur [7]. Bu hastalığın birincil tedavisi psikolojik terapidir. Bunun medikal tedavi ve seksüel danışmanlık ile kombine edilmesi gerekmektedir. Medikal tedavi öncesi hastalığın altta yatan psikojenik ve organik sebeplerinin ayrıntılı olarak değerlendirilmesi gerekmektedir. Medikal tedavide topikal kremler, selektif seratonin geri alım inhibitörleri (SSRI), fosfodiesteraz 5 (PDE-5) inhibitörleri ve tramadol kullanılmaktadır [7, 8]. Toplumsal ve kültürel tabular nedeni ile cinsel sorunlar hekime başvurmadan daha gizli şekilde çözülmeye çalışılmaktadır. İnternet, televizyon ve gazete reklamları aracılığı ile bitkisel olduğu ve zararlı olmadığı iddia edilen ürünler bu nedenle tercih edilmektedir.

İlaçlar birçok güvenlik testinden geçtikten sonra piyasaya çıkarılmaktadır. Bu testlerden geçtikten sonra dahi ilaçların bir kısmı yan etkiler ve ilaç etkileşimleri nedeni ile kullanımdan kaldırılmaktadır. Bitkisel ürünlerin ise yan etki değerlendirilmesi rutin olarak yapılmamaktadır. Bu ürünleri satanların ortaya çıkan yan etkileri bildirme zorunluluğu da yoktur. Bu nedenle olası yan etiler ve ilaç etkileşimleri hakkında bilgiler yetersizdir. Fibrinolitik sistem üzerine olan etkileri ve antikoagulanlar ile etkileşimi yeni yeni gündeme gelmeye başlamıştır [2, 3]. Bu etkileri nedeni ile iskemik vasküler hastalıkların etiyolojisinde yer alabileceği düşünülmektedir. Besinler ile etkileşimi ise henüz bilinmemektedir. 
Bizim hastamızda da iskemik beyin damar hastalığının etiyolojisinde bu ürünlerin olabileceği düşünülmüştür. Kullanılan bitkisel üründeki bileşenler ile ilişkili inme olguları bildirilmemiştir. Ancak içeriğindeki kafeinin kan basıncı değişiklikleri yaparak inme etiyolojisinde rol alabildiği bilinmektedir. Ayrıca bu bileşenlerin birbiri ile olan etkileşimi de tromboza yatkınlık oluşturabilmektedir.

İskemik inme toplumda sık görülmesine rağmen gençlerde daha azdır. Özürlülüğe sebep olan hastalıklar içerisinde birinci sırada yer almaktadır [9]. İskemik inmelerin kırk beş yaşından daha erken görülmesine genç iskemik inme denilmektedir. İnsidansının 3,411,4/100,000 arasında olduğu bildirilmiştir [10]. İleri yaşlardaki hastalara göre etiyolojik risk etmenlerinde farklııklar bulunmaktadır. Bu duruma en sık kardiyolojik hastalıklar neden olmaktadır. Diğer risk faktörleri ise büyük arter aterosklerozu, küçük damar hastalığı, hipertansiyon, diabetes mellitus, dislipidemi, tromboza yatkınlık oluşturan genetik ve hematolojik hastalıklardır. Bazı hastalarda ise herhangi bir risk etmeni tespit edilememektedir. Bu durum sebebi saptanamamış inme olarak adlandırılmaktadır [11]. Bizim hastamızda ise kardiyak, metabolik, genetik, hematolojik, vaskülitik ve enfektif inceleme sonuçları normaldi. Yalnızca karotis arter distalinde $4 \times 2 \mathrm{~mm}$ boyutlarında kalsifiye stabil plak izlendi. İskemi, ön ve arka vasküler sistemleri birlikte etkilediğinden mevcut durum büyük arter aterosklerozuna bağlanmadı. Etiyolojiyi açıklayabilecek tüm sebepler ekarte edildikten sonra sebebi saptanmamış inme düşünüldü. $\mathrm{Bu}$ hastalarda aile öyküsünün, madde ve ilaç kullanımının ayrıntılı olarak sorgulanması önemlidir. Hekim tavsiyesi olmadan kullanılan ilaçların doz aşımı olmasa da tromboza yatkınlık oluşturabileceği unutulmamalıdır.

Sonuç olarak, iskemik inmenin etiyolojisinde birçok risk etmeni bulunmaktadır. Ancak bazı hastalarda hiçbir risk etmeni tespit edilememektedir. $\mathrm{Bu}$ durumda kullanılan tüm ilaçlar ayrıntılı olarak sorgulanmadır. Özellikle etki mekanizması ve yan etkileri iyi bilinmeyen, bitkisel olduğu iddia edilen ürünlerin sorgulanmasına da özen gösterilmelidir. Hastalar bitkisel olan zararsızdır diye düşünüp bu ilaçları söyleme gereği duymayabilir. Ayrıca bizim gibi içe kapalı toplumlarda cinsel sorunlarının dile getirilmesini ve ilaç kullanımının bilinmesini istemeyebilir. Bu tip ilaçların hekim kontrolü dışında kullanılması bizim hastamızda da olduğu gibi ciddi sorunlar doğurabilmektedir. Bu yüzden bu ilaçların ulaşımı ve satışı ile ilgili gerekli düzenlemelerin yapılması gerekmektedir.

Çıkar İlişkisi: Yazarlar çıkar ilişkisi olmadığını beyan eder.

\section{Kaynaklar}

1. Ernst E, Pitler MH. Risks associated with herbal medicinal products. Wien Med Wochenschr 2002;152:183-189.

2. Gianni LM, Dreitlein WB. Some popular OTC herbals can interact with anticoagulant therapy. US Pharmacist 1998;23:80-86.

3. Bush TM, Rayburn KS, Holloway SW, et al. Adverse interactions between herbal and dietary substances and prescription medications: a clinical survey. Altern Ther Health Med 2007;13:30-35.

4. Mert DG, Özen NE. Genel psikiyatri polikliniğine başvuran kadın hastalarda cinsel işlev bozukluğu ve ilişkili sosyokültürel parametrelerin değerlendirilmesi. Klinik Psikiyatri Derg 2011;14:85-93.

5. Hariri AG, Karadag F, Gurol DT, Aksoy UM, Tezcan AE. Sexual problems in a sample of Turkish psychiatric population. Compr Psychiatry 2009;50:353-360.

6. İncesu C. Cinsel işlevler ve cinsel işlev bozuklukları. Klinik Psikiyatri Derg 2004;7:3-13.

7. Hatzimouratidis K, Amar E, Eardley I, et al. Guidelines on male sexual dysfunction: erectile dysfunction and premature ejaculation. Eur Urol 2010;57:804-814.

8. Waldinger MD, Zwinderman $A H$, Schweitzer $D H$, Olivier B. Relevance of methodological design for the interpretation of efficacy of drug treatment of premature ejaculation: a systematic review and meta-analysis. Int J Impot Res 2004;16:369-381.

9. Kumral E, Balkır K. İnme epidemiyolojisi. In: Balkan S, editör. Serebrovasküler hastalıklar. 1. baskı, Ankara: Güneş Kitapevi, 2002;38-40.

10. Groppo E, De Gennaro R, Granieri G, et al. Incidence and prognosis of stroke in young adults: a populationbased study in Ferrara, Italy. Neurol Sci 2012;33:53-58.

11. Dash D, Bhashin A, Pandit AK, et al. Risk factors and etiologies of ischemic strokes in young patients: a tertiary hospital study in north India. J Stroke 2014;16:173-177. 